\title{
Glacier changes during the past century in the Gangrigabu mountains, southeast Qinghai-Xizang (Tibetan) Plateau, China
}

\author{
LIU Shiyin, ${ }^{1,2}$ SHANGGUAN Donghui, ${ }^{1}$ DING Yongjian, ${ }^{1}$ HAN Haidong, ${ }^{1}$ \\ XIE Changwei, ${ }^{1}$ ZHANG Yong, ${ }^{1}$ LI Jing, ${ }^{1}$ WANG Jian, ${ }^{1}$ LI Gang ${ }^{1}$ \\ ${ }^{1}$ Laboratory of Cryosphere and Environment, Cold and Arid Regions Environmental and Engineering Research Institute, \\ Chinese Academy of Sciences, 260 Donggang West Road, Lanzhou 730000, China \\ E-mail: liusy@ns.Izb.ac.cn \\ ${ }^{2}$ Institute for Tibetan Plateau Research, Chinese Academy of Sciences, Beijing 100029, China
}

\begin{abstract}
The present research focuses on glacier changes in the southeast of the Qinghai-Xizang (Tibetan) Plateau, where most of the temperate glaciers in China are located. Our results show that the 102 measured glaciers in the region have all retreated between 1915 and 1980, with total area and volume decreases of $47.9 \mathrm{~km}^{2}$ and $6.95 \mathrm{~km}^{3}$, respectively. The extrapolated mass loss of all glaciers in the Gangrigabu mountains amounted to $27 \mathrm{~km}^{3}, 9.8 \%$ of the ice mass in 1915 . Between 1980 and 2001, glaciers in the region have also experienced a general retreat; however, up to $40 \%$ of the glaciers were advancing. Our analysis demonstrates that precipitation in the studied area has increased substantially since the mid-1980s. This precipitation increase is likely to bring about a positive mass balance for glaciers in the region, so that the retreat of retreating glaciers might slow down or even turn into advance. Considering the sensitivity of the temperate glaciers in the region and the uncertainty in climate projections, more attention must be paid to glacier changes in the southeast Tibetan Plateau region.
\end{abstract}

\section{INTRODUCTION}

Recent studies indicate that most alpine glaciers around the world have been retreating during the past century, especially in the most recent decades, due to climate change (Folland and others, 2001). Of all retreating glaciers in the world, temperate glaciers exhibited the most intensive mass loss during the period (Church and others, 2001). In this context, we are interested in whether temperate glaciers in China have experienced widespread retreat during the same period. In this study we choose the Gangrigabu mountains, located in the southeast of the Qinghai-Xizang (Tibetan) Plateau, as an experimental region which falls into the subtropical mountainous zone. Glaciers in the region are referred to by Chinese scientists as monsoonal maritimetype glaciers, mainly nourished through the Indian monsoon precipitations ( $\mathrm{Li}$ and others, 1986). The southeast of the Tibetan Plateau is one of the important regions with maritime glacier development (Shi and Liu, 2000). It is estimated that annual precipitation at the equilibrium-line altitude (ELA) of glaciers in the region is about 2500$3000 \mathrm{~mm}$ of water, and the mean summer air temperature is usually above $1^{\circ} \mathrm{C}$ (Shi and Bai, 1988). Previous studies indicated that the southeast Tibetan Plateau is a key region of intense debris-flow disasters, threatening local human life and transportation, due to the combined influences of strong glacier ablation and high precipitation (Zeng and others, 2000).

The Gangrigabu mountains are located on the eastern end of the Nyainqêntanglha mountains in southeast Tibet, which extend about $280 \mathrm{~km}$ from northwest to southeast (Fig. 1). This region belongs to a tributary of the Yalung Zangbu river, one of the upper basins of the Brahmaputra river. According to the Chinese Glacier Inventory (CGI) (Mi and others, 2002), there are 1320 glaciers in the range, with a total area and volume of $2655.2 \mathrm{~km}^{2}$ and $260.3 \mathrm{~km}^{3}$, respectively. Yalong glacier (CGI code: 5O282B37) is the largest glacier in the region $\left(32.5 \mathrm{~km}\right.$ long and $191.4 \mathrm{~km}^{2}$ in surface area). Several other large glaciers have been observed recently, for example, Azha glacier (5O292B181, with a narrow, long ablation area $16.7 \mathrm{~km}$ long and $13.75 \mathrm{~km}^{2}$ in area) and Xueyouzou glacier (5O291B179, $21.5 \mathrm{~km}^{2}$ in area) (Li and others, 1986). Up to $50 \%$ of the glaciers in this region are small in area, ranging between 0.25 and $2 \mathrm{~km}^{2}$ (Fig. 2), and the $19.1 \%$ of glaciers with surface area between 2 and $16 \mathrm{~km}^{2}$ occupy $51.2 \%$ of the total glacier area in the region.

Many investigations show that the climate in western China experienced three cold periods between the 15th and 19th centuries, during the so-called Little Ice Age (LIA), which resulted in advances of most glaciers. Three end moraines and lateral moraines formed during the LIA can occasionally be found around glaciers in western China (Wang, 1991; Shi and Liu, 2000; Liu and others, 2002, 2003; $\mathrm{Pu}$ and others, 2002; Wang and Ding, 2002). The period AD 1601-90 was the coldest period, as recorded in the Guliya ice core (Yao and others, 1995), and the dramatic decline in air temperature at this time is believed to correlate with the so-called Maunder Minimum (AD 1645-1715) in solar irradiance (Wang and others, 2000). The three end moraines below Ürümqi glacier No. 1 at the head of the Ürümqi river have been dated to $1538 \pm 20,1777 \pm 20$ and $1871 \pm 20$ years BP by field investigation and lichenometry (Chen, 1988; Wang, 1993; Shi and Liu, 2000).

A field investigation on Azha glacier on the south slope of the Gangrigabu mountains in 1973 did not find end moraines close to the present glacier front, but there were two relatively new lateral moraines beside the middle of the ablation area at an elevation of $3600 \mathrm{~m}$ ( $\mathrm{Li}$ and others, 1986). Spruce trees at least 50 years old grow on these lateral moraines. The glacier delineated by the inner lateral moraine might have expanded to a lower position than that marked by the outer lateral moraine. From the tree-ring width of a spruce growing at a higher elevation of the lateral 


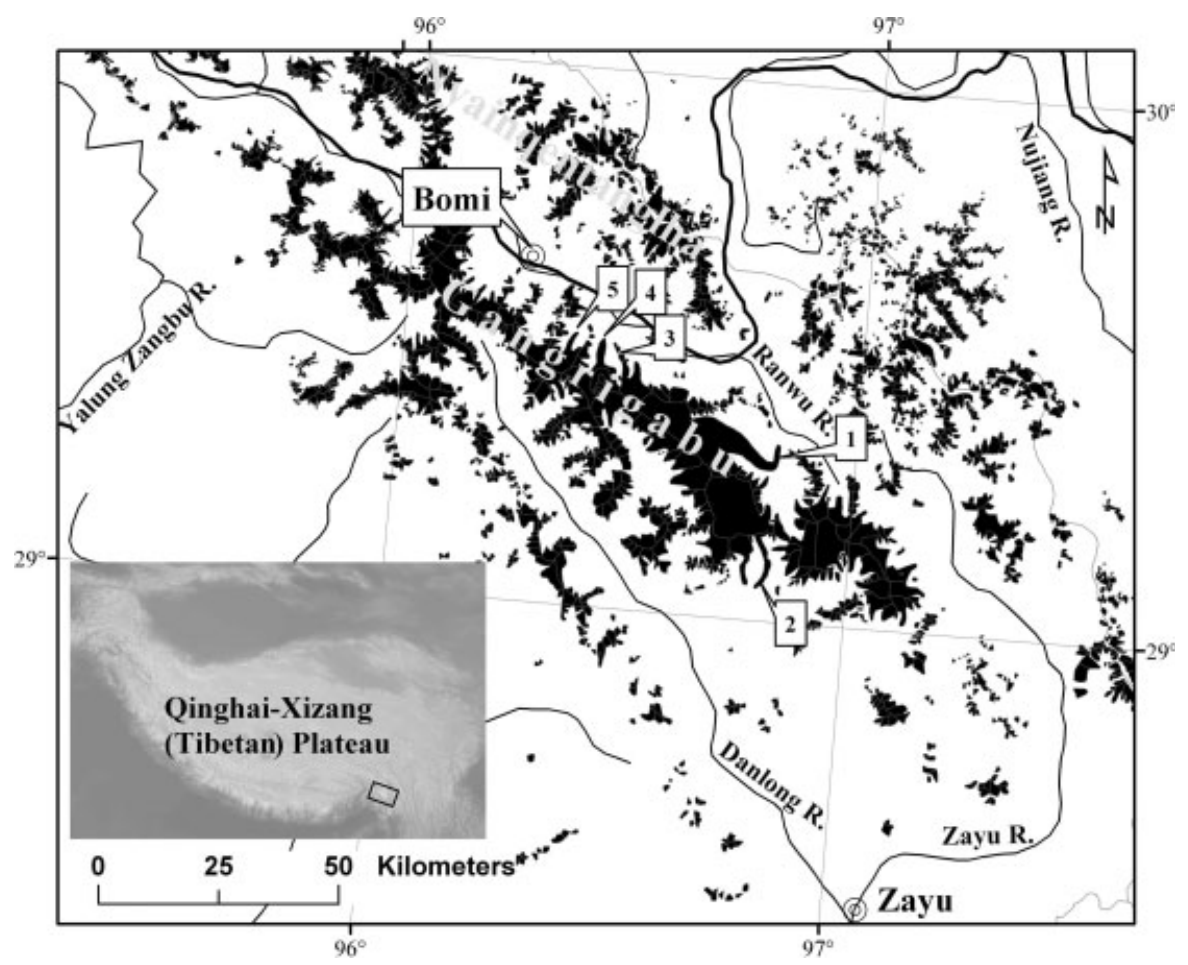

Fig. 1. Sketch map of glaciers and meteorological stations in the Gangrigabu mountains, southeastern Tibet. Flags: 1. Yalong glacier; 2. Azha glacier; 3. glacier 5O282B0099; 4. glacier 5O282B0123; and 5. glacier 5O282B0136.

moraine, Li and others (1986) concluded that the inner lateral moraine might have been formed in the 1920 s as the result of a cold stage during 1889-1912. Although we refer to the 1920s here, we use 1915 in the rest of this paper as the latest advance of glaciers during the LIA. This is confirmed by detailed dendroclimatological studies by $\mathrm{Wu}$ and others (1988).

\section{DATA AND METHODS}

We have used aerial photographs taken in October 1980, topographic maps made from these photographs, one $19 \mathrm{~m}$ resolution China-Brazil Earth Resources Satellite (CBERS) image acquired on 30 January 2001 and one $30 \mathrm{~m}$ resolution Landsat Thematic Mapper (TM) image taken on 26 October 1999, as well as a digital elevation model (DEM) of $90 \mathrm{~m}$ resolution derived from 1:250000 topographic maps, to determine glacier changes in the Gangrigabu mountains. The Landsat TM and CBERS images were registered to the maps, which use the Gauss Kruger projection and Krasovsky spheroid. To improve the accuracy of the georegistration, we used the DEM to orthorectify the images. The geometric correction residual errors are about $1-3$ pixels $( \pm 19-57 \mathrm{~m}$ for CBERS and $\pm 30-90 \mathrm{~m}$ for TM) because of difficulties in choosing good registration points in snow-covered areas. The threshold-of-band-ratio method (Zhang and others, 2001; Kääb and others, 2002) to automatically identify glaciers on the images is not ideal because snow cover usually extends to unglaciated surfaces. Therefore, terminus boundaries of easily identified glaciers on TM and CBERS images were modified based on already validated and vectorized boundaries of glaciers on the 1980 maps, as applied in the CGI. Considering errors in visual identification of glacier boundaries, we only selected those glaciers with length changes larger than $57 \mathrm{~m}$ on the CBERS image or $90 \mathrm{~m}$ on the TM image. Extents of glaciers in 1915 were identified by using stereoscopic aerial photos, on which the easily observed

Table 1. Changes of 102 glaciers in the Gangrigabu mountains, $1915-80$ ( $\Delta$ : change)





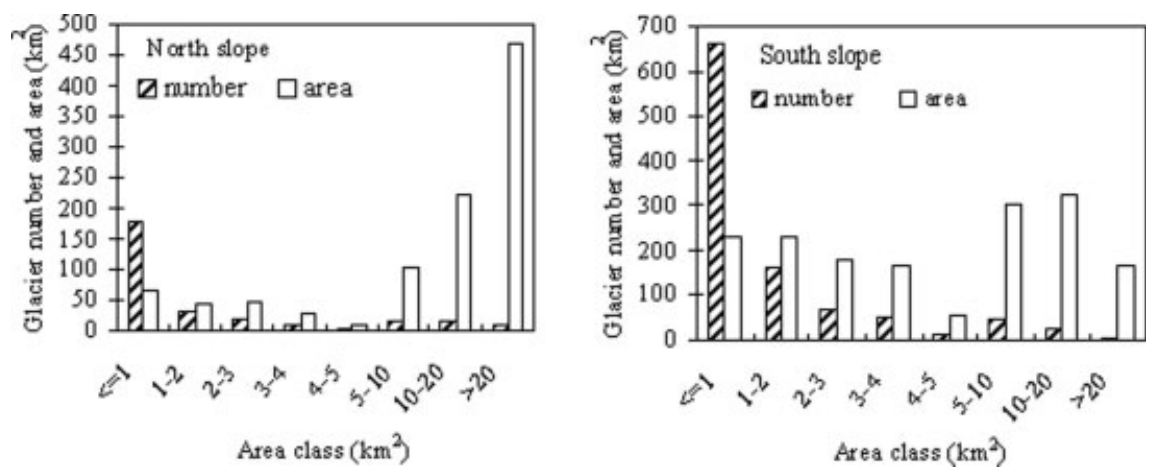

Fig. 2. Distribution of total number and area of glaciers by area class on the north and south slopes of the Gangrigabu mountains.

innermost lateral and end moraines with the least plant and tree cover were taken as the extents reached by the glaciers in 1915. Such identification could not easily be made on all the glaciers in the region, because the end moraines were generally washed out, or lateral moraines were eroded due to extensive meltwater and high precipitation flows. In addition, we conducted a field investigation in 2001 in a glacierized basin where Yalong glacier is located to validate this kind of interpretation and classification of glaciers on satellite images, including a global positioning system (GPS) survey on several small glaciers. The volumes of glaciers were calculated using the statistical regression relation:

$$
V=0.04 S^{1.35},
$$

where $V$ is glacier volume in $\mathrm{km}^{3}$, and $S$ is glacier area in $\mathrm{km}^{2}$. This equation was derived by Liu and others (2003) based on thickness measurements by an ice-penetrating radar on 22 glaciers in the Tien Shan and Qilian Shan, western China.

\section{RESULTS}

\subsection{Glacier changes, 1915-80}

We identified and measured 102 glaciers from aerial photos on the north and south slopes of the Gangrigabu mountains (Table 1). This represents the extent of glaciers in 1915. We found that all glaciers retreated between 1915 and 1980 . The total area loss of all these glaciers is $47.9 \mathrm{~km}^{2}$, and total volume loss is $6.95 \mathrm{~km}^{3}$. On average, these glaciers have retreated $1095 \mathrm{~m}$ in length, and terminus elevation has increased $158 \mathrm{~m}$. The surface-area and ice-volume decrease amounted to $4.3 \%$ and $4.4 \%$ of the respective totals in 1915 . Glaciers on the south slope of the mountains experienced more obvious retreat than those on the north slope. The average glacier shrinkage in the region is $0.74 \mathrm{~km}^{2} \mathrm{a}^{-1}$ in area, $0.11 \mathrm{~km}^{3} \mathrm{a}^{-1}$ in volume and $16.8 \mathrm{~m} \mathrm{a}^{-1}$ in length, and the glacier front positions have risen by $2.4 \mathrm{~m} \mathrm{a}^{-1}$.

\subsection{Glacier changes, 1980-2001}

On CBERS and TM images we can only identify 88 glaciers because of the snow cover. Their changes during these 20 years are listed in Table 2. Of these glaciers, $60 \%$ were retreating and the rest were advancing. The decreases and increases represent $2.8 \%$ of the total area of retreating glaciers and $2.9 \%$ of the total area of advancing glaciers. Overall, glaciers in the region lost an area of $2 \mathrm{~km}^{2}$. The volume of 52 retreating glaciers decreased by $1.73 \mathrm{~km}^{3}$, and the volume of 36 advancing glaciers increased by $1.42 \mathrm{~km}^{3}$ based on Equation (1). Thus the total volume decrease is $0.31 \mathrm{~km}^{3}$.

\section{DISCUSSION}

\subsection{Characteristics of glacier changes}

The relative change of glaciers was small between 1915 and 1980, as shown in Table 1. This may be due to the weighting effect of large glaciers; the average area of the 102 glaciers is $10.5 \mathrm{~km}^{2}$ (Table 1). Su and Shi (2000) investigated 245 glaciers in the drainage area of the Zayu (or Chayu) river on the south slope of the range, and found that these glaciers had lost $36.9 \%$ of their area between 1915 and 1980. The mean size of their sampled glaciers is very small, averaging only $1.41 \mathrm{~km}^{2}$, but their result verifies that small glaciers in the region have shrunk considerably.

Glacier changes are different in different parts of the mountains between 1915 and 1980. Glaciers in the southeast of the range underwent a large area reduction

Table 2. Changes of 88 glaciers in the Gangrigabu mountains, 1980-2001

\begin{tabular}{|c|c|c|c|c|c|c|c|c|c|c|}
\hline \multirow[t]{3}{*}{ Drainage basin } & \multirow[t]{3}{*}{ CGI code } & \multicolumn{5}{|c|}{ Retreating glaciers } & \multicolumn{4}{|c|}{ Advancing glaciers } \\
\hline & & \multirow[t]{2}{*}{ Number } & \multirow{2}{*}{$\begin{array}{l}\text { Area } \\
\mathrm{km}^{2}\end{array}$} & \multicolumn{2}{|c|}{ Area change } & \multirow{2}{*}{$\begin{array}{c}\text { Length } \\
\text { change } \\
\text { m }\end{array}$} & \multirow[t]{2}{*}{ Number } & \multirow{2}{*}{$\begin{array}{l}\text { Area } \\
\mathrm{km}^{2}\end{array}$} & Area change & \multirow{2}{*}{$\begin{array}{c}\text { Length } \\
\text { change } \\
\text { m }\end{array}$} \\
\hline & & & & $\mathrm{km}^{2}$ & $\%$ & & & & $\mathrm{~km}^{2}$ & \\
\hline Ranwu river on north slope & $5 \mathrm{O} 282 \mathrm{~A}, \mathrm{~B}$ & 16 & 273.1 & $-4.5 \pm 0.38$ & -1.6 & $-262 \pm 57$ & 8 & 140.9 & $1.5 \pm 0.271 .1$ & $435 \pm 57$ \\
\hline Total/average & & 52 & 444.6 & $-12.4 \pm 0.66$ & -2.8 & $-237 \pm 57$ & 36 & 353.2 & $10.4 \pm 0.572 .9$ & $389 \pm 57$ \\
\hline
\end{tabular}



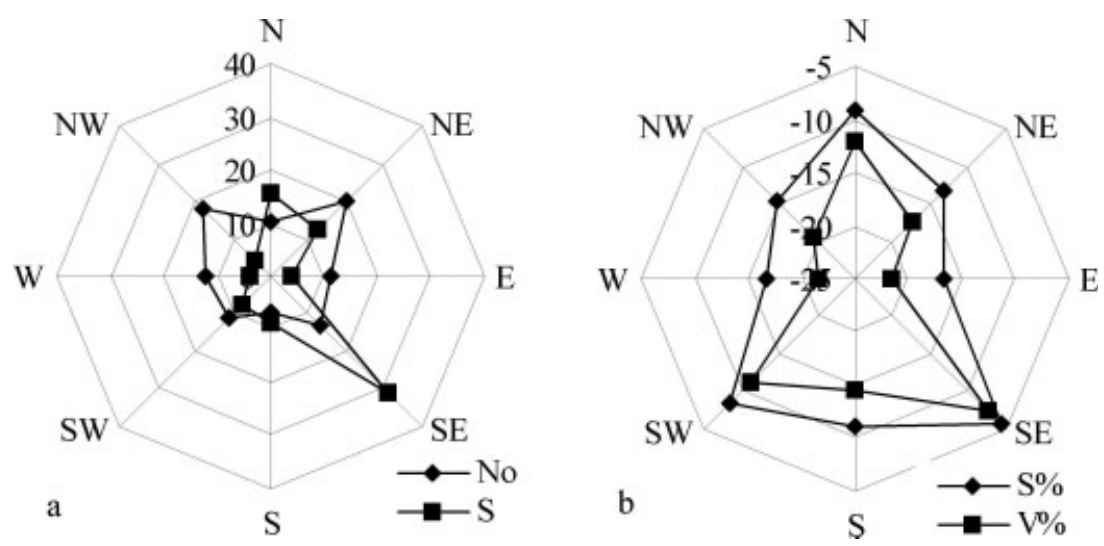

Fig. 3. (a) Number (No) and mean area $(\mathrm{S})$ and (b) relative changes in area $(\mathrm{S} \%)$ and volume $(\mathrm{V} \%)$ of measured glaciers on various slopes of the Gangrigabu mountains.

but a small relative change, while glaciers on the east, west and northwest sides of the mountains experienced a large proportional reduction of $12.1 \%$ and $15.6 \%$ (Fig. 3) in area and volume, respectively, because of their smaller sizes. This indicates that the change of a single glacier cannot be used to represent the changes of all glaciers in a region.

Glaciers in the region exhibited diverse responses during the last two decades, and large glaciers played an important role in the total changes in area and volume. As shown in Figure 4, the area reduction of 11 glaciers $>10 \mathrm{~km}^{2}$ was $5.4 \pm 0.29 \mathrm{~km}^{2}$ which has contributed $43.7 \%$ of the total area decrease for retreating glaciers; while the area increase of 12 glaciers $>10 \mathrm{~km}^{2}$ was $5.7 \pm 0.31 \mathrm{~km}^{2}$ which accounts for $54.8 \%$ of the total area increase of the advancing glaciers. The area reduction of 22 glaciers $<1 \mathrm{~km}^{2}$ only amounts to $14.3 \%$ of the total area reduction, and the area increase of 10 glaciers of this size amounts to $19.9 \%$ of the total area increase due to glacier advance. For example, Yalong glacier (CGI code: 5O282B37) lost $1534 \mathrm{~m}$ in length and $2.23 \mathrm{~km}^{2}$ in area between 1980 and 2001. Although the area decrease of the glacier was $1.2 \%$ of its area in 1980 , it accounts for $18 \%$ of the area decrease of 52 retreating glaciers. Azha glacier (5O291B0179) retreated $1627 \mathrm{~m}$ between 1980 and 2001, and the terminus elevation increased $60 \mathrm{~m}$ from $2540 \mathrm{~m}$ a.s.l. in 1980. This glacier only decreased $0.44 \mathrm{~km}^{2}$ in area because of its long, narrow ablation area. A few large advancing glaciers contributed a large portion of the area and volume changes of all advancing glaciers.

Table 3. Calculated changes in glacier area, length, terminus elevation and volume of all 1320 glaciers in the Gangrigabu mountains. For 1915, 102 glaciers were sampled; area, length and terminus-elevation estimates for the remaining 1218 glaciers without measurements are from Equations (2-4). Volume estimates are from Equation (1)

\begin{tabular}{lllll}
\hline & 1915 & 1980 & Change & $\%$ \\
\hline Total area $\left(\mathrm{km}^{2}\right)$ & 3079.6 & 2655.2 & -424.4 & -13.8 \\
Mean length $(\mathrm{km})$ & 2.40 & 1.69 & -0.71 & -29.6 \\
Mean terminus elevation $(\mathrm{m})$ & 4427 & 4575 & 148 & \\
Total volume $\left(\mathrm{km}^{3}\right)$ & 279.49 & 252.10 & -27.4 & -9.8 \\
\end{tabular}

For example, glaciers 5O282B0136 and 5O282B0123 on the northwestern slope of the Gangrigabu mountains have advanced 1117 and $1762 \mathrm{~m}$, and their areas have increased 0.51 and $0.49 \mathrm{~km}^{2}$, respectively.

The general pattern of glacier shrinkage during the last two decades can be attributed to climate warming in the region, while a less obvious total area reduction is due to the contribution of advancing glaciers that are responding to the generally increasing trend of precipitation in the region. Climate records of the nearby meteorological stations Zayu $\left(28^{\circ} 43^{\prime} \mathrm{N}\right.$, $99^{\circ} 17^{\prime} \mathrm{E}$; 2423 ma.s.l.; starting in 1969) and Bomi $\left(29^{\circ} 52^{\prime} \mathrm{N}\right.$, $95^{\circ} 46^{\prime} \mathrm{E} ; 2736 \mathrm{~m}$ a.s.l.; starting in 1961) represent climate change well in our study region. There is an upward trend in the warm-season (MaySeptember) mean temperature, with a rise of $0.3-0.5^{\circ} \mathrm{C}$, and obvious warming starting in 1977 and an increase in precipitation starting in 1986 at both stations, with a larger positive precipitation anomaly at Bomi than at Zayu. According to temperature and precipitation data between 1961 and 1995 within a block of $25-35^{\circ} \mathrm{N}, 94-100^{\circ} \mathrm{E}$ gridded by $0.5^{\circ}$, provided by the Hadley Centre for Climate Prediction and Research, Reading, UK, (New and others, 2000) a transition of warm-season mean temperature from decrease to increase occurred in 1976, and a notable increase of warm-season precipitation after 1984 (Fig. 5). Warming usually brings about a lower snowfall-torainfall ratio in precipitation and thus lower glacier accumulation than under a cooling climate, which leads to more negative glacier mass balance. However, when precipitation increases, glaciers may be in positive balance. Based on the decadal mean precipitation, the anomaly of annual precipitation in the 1980s and 1990s at Bomi shows obvious change to over $20 \%$ above the mean of the whole observation period (Shi and others, 2006) from $40 \%$ below the mean in the 1960 s. For glaciers in the region, where the estimated annual precipitation is about $2500-3000 \mathrm{~mm}$ at the ELAs, such an increase in precipitation means an increase in accumulation of 500$600 \mathrm{~mm}$ if all increased precipitation is snowfall and varies by the percentage indicated above. Due to differences in geometry and mass-balance gradients, different glaciers may respond differently to these combined climatic changes. The fact that about $40 \%$ of the glaciers have advanced during the last two decades indicates that these glaciers might have a strong response to the recent precipitation increase in the region. 


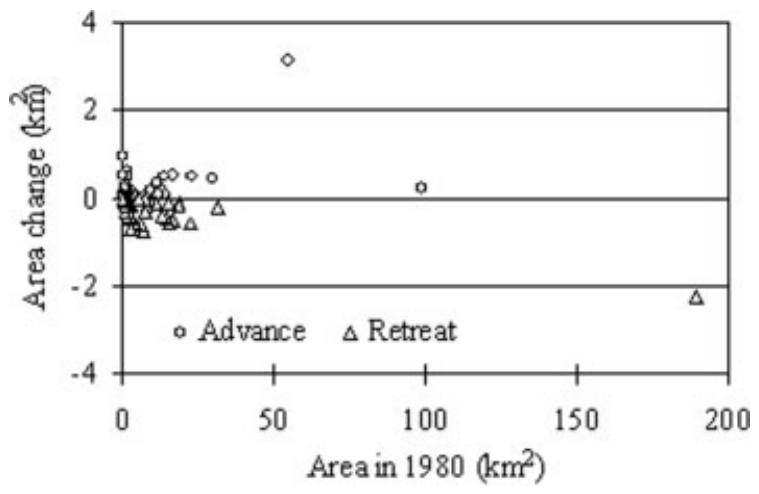

Fig. 4. Absolute length changes of the retreating and advancing glaciers of different sizes between 1980 and 2001 in the Gangrigabu mountains.

\subsection{The impact of glacier changes on water resources}

Many studies (Wang, 1991; Warrick and others, 1996; Liu and others, 2002; Pu and others, 2002; Wang and Ding, 2002) have shown that glaciers in western China and other parts of the world were in retreat after the end of the LIA. Although some glaciers have been found to be advancing recently in western China, we did not find that they have regained the sizes they had during the coldest period of the LIA. If we can find a statistically significant relation between the extents of glaciers in 1915 and in 1980 in this case, it may be reasonable to extrapolate the relationship to other glaciers in this region without any measurements. Based on linear regression analysis of the extent parameters of the 102 sampled glaciers, we find such relationships exist for glaciers in 1915 and 1980 in the study region. They are expressed as:

Area:

$S_{\mathrm{I}}=1.0175 S_{\mathrm{m}}+0.2863 \quad\left(n=102, R^{2}=0.99, \alpha=0.01\right)$

Length:

$L_{\mathrm{I}}=1.0941 L_{\mathrm{m}}+0.5506 \quad\left(n=102, R^{2}=0.98, \alpha=0.01\right)$

Terminus elevation:

$$
E_{\mathrm{l}}=1.0157 E_{\mathrm{m}}-220 \quad\left(n=102, R^{2}=0.99, \alpha=0.01\right),
$$

where $S, L$ and $E$ represent the area, length and terminus elevation of a glacier, respectively, and the subscripts I and m denote these parameters in 1915 and 1980, respectively.

The changes of area, volume, length and terminus elevation of all 1218 glaciers without measurements in the region between 1915 and 1980 are calculated using the above relations, and the results are listed in Table 3. When the area of such a glacier is calculated using Equation (1), we can estimate the 1915 and 1980 volumes from $V=0.04 S^{1.35}$ and the glacier change between 1915 and 1980. The total area and volume of glaciers in the region have decreased $13.8 \%$ and $9.8 \%$, respectively, in these 65 years. The average decrease in length of all the glaciers was $710 \mathrm{~m}$, and average terminus elevation migration was $148 \mathrm{~m}$ upward. This ice wastage is equivalent to $249.2 \times 10^{8} \mathrm{~m}^{3}$ of water, with ice density of $0.91 \mathrm{~g} \mathrm{~cm}^{-3}$.
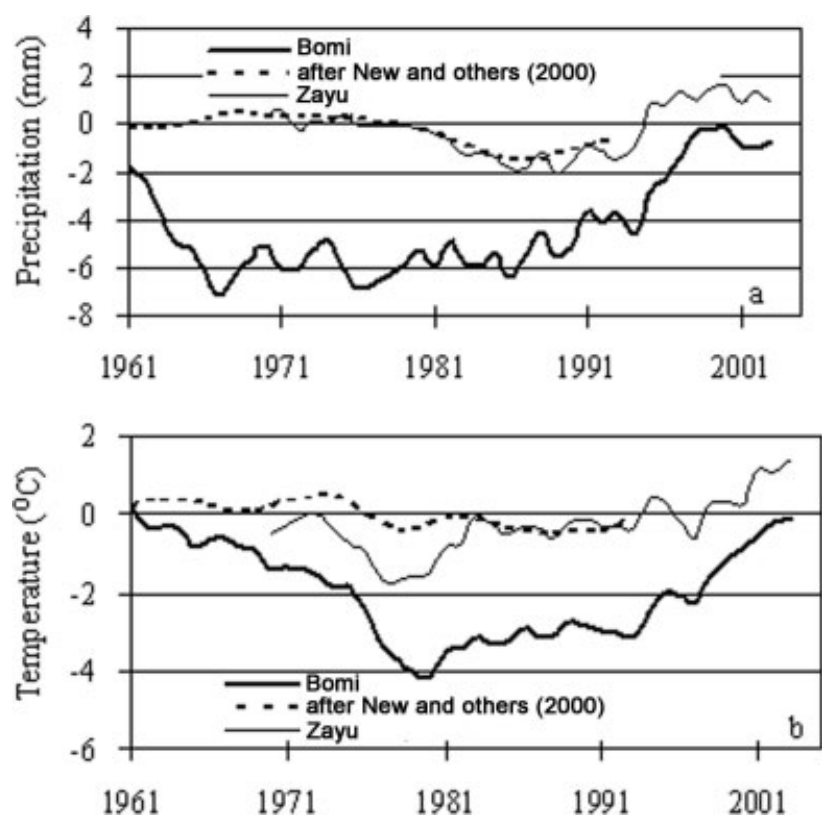

Fig. 5. Warm-season (May-September) mean daily precipitation (a) and average air temperature (b) between 1961 and 2003 at Bomi and Zayu meteorological stations, and corresponding results derived from $0.5^{\circ}$ gridded data in the region $25-35^{\circ} \mathrm{N}, 94-100^{\circ} \mathrm{E}$ (data are from Hadley Centre; see New and others, 2000). Curves are based on the cumulated anomaly of the precipitation and air temperature.

\subsection{Warming rate estimated from glacier changes}

Liu and others (2003) have found that the upward migration of glacier terminus elevation $\left(\Delta Z_{\text {end }}\right)$ can represent the rise of the ELA ( $\triangle E L A)$ for small $(<1 \mathrm{~km}$ long) retreating glaciers in western China by the relation $\Delta Z_{\text {end }}=1.02 \Delta \mathrm{ELA}$. Of the 102 glaciers with measured changes in the period 1915-80, 30 are shorter than $1 \mathrm{~km}$. The terminus elevations of these 30 glaciers have migrated upwards by $20-240 \mathrm{~m}$; the average is $125 \mathrm{~m}$. From the relation above, this is equal to $122 \mathrm{~m}$ of ELA change.

The ELA change of a glacier is the result of the yearly variations in mass balance, thus reflecting climate change in the region in which the glacier is located. However, the amplitude of ELA variation on a glacier depends on the sensitivity of the ELA to climate parameters. The results of Zhang and others (1998), based on the sensitivity analysis of ELA to climate change, reveal that the ELA of glacier AX010 in the Nepal Himalaya, a representative monitored temperate glacier, will migrate upwards by $124 \mathrm{~m}$ with a rise of $1^{\circ} \mathrm{C}$ in air temperature and an increase of $20 \%$ in precipitation; while the upward migration is increased to $152.9 \mathrm{~m}$ with a $1^{\circ} \mathrm{C}$ rise in air temperature without precipitation change. Supposing the result of glacier AX010 to be applicable in this region, ELA migration in our study area corresponds to a warming of $0.8^{\circ} \mathrm{C}$ between 1915 and 1980 if there was no change in precipitation. This is the same as the value estimated by an atmospheric lapse rate of $0.65^{\circ} \mathrm{C}(100 \mathrm{~m})^{-1}$. Our result is quite similar to that derived from historic documents and dendroclimatological records in the south and the southeast Tibetan Plateau (Lin and Wu, 1984; Wu and others, 1989). Through a comprehensive summarization of weather changes, phenological observations, as well as natural disasters in Lhasa recorded in an official's diary during the late Qing Dynasty, Lin and Wu (1984) concluded 
that it was much colder and wetter in the 1910s than in the early 1980s. In addition, a tree-ring index established from trees in Linzhou County $\left(30^{\circ} 14^{\prime} \mathrm{N}, 9^{\circ} 22^{\prime} \mathrm{E} ; 4320 \mathrm{~m}\right.$ a.s.l.) showed that the early 1910 s were warmer by $1.1^{\circ} \mathrm{C}$ than the late 1980s (Wu and others, 1989). The temperature rise derived from ELA migration and the above-mentioned analysis may be reasonable if the rise in air temperature indicated by ELA variation of glaciers in the region is accepted. This suggests that the warming between 1915 and 1980 was very pronounced. However, the influence of precipitation on ELA changes in the region could not be assessed due to the lack of long-term precipitation records.

\section{SUMMARY AND CONCLUSIONS}

Through monitoring changes of a limited number of glaciers and extrapolation by statistical relations based on the sampled glaciers, we conclude that glaciers in the Gangrigabu mountains have retreated $13.8 \%$ in area and $9.8 \%$ in volume, respectively, from 1915 to 1980 . It is estimated that glacier shrinkage in the region could be the result of a temperature rise of $0.8^{\circ} \mathrm{C}$ in this period, as calculated from ELA upward migration. Glaciers in the region have lost a total ice mass equivalent to $249.2 \times 10^{8} \mathrm{~m}^{3}$ of water during the time-span 1915-80. In the most recent two decades, our monitored glaciers demonstrated a general trend of retreat; however, over $40 \%$ of the glaciers advanced.

According to the analysis of air-temperature and precipitation changes at adjacent meteorological stations in the study area, climate warming has been a regional feature during recent decades, especially since the late 1970 s. Precipitation exhibited an obvious general increase, and, unlike temperature, an obvious precipitation increase occurred in the mid-1980s. Glacier advance may be related to the particular dynamic properties of different glaciers responding to the combined impact of increase in both air temperature and precipitation, especially the obvious increase of precipitation since 1986. Because of the possible positive mass balance due to increased precipitation from the mid-1980s and in the 1990s, the retreat of retreating glaciers might slow down; the observed expansion of some glaciers, which were either advancing, retreating or stable before the year with precipitation increase, was likely to increase during the period of higher precipitation. Considering the widespread retreat and general retreat trend of glaciers between 1915 and 1980 as well as after 1980, we can expect that glaciers in the region will be subject to accelerated shrinkage under the influence of a projected continuous warming in this century if the observed increase in precipitation does not continue or decreases. Water resources will be seriously affected by the resulting tremendous decrease in glacier runoff.

\section{ACKNOWLEDGEMENTS}

We are grateful to C. Braun, G. Holdsworth and A. Rivera for detailed reviews, comments and suggestions, which greatly improved the quality of the paper. We are indebted to $\mathrm{H}$. Brecher for his dedicated efforts which helped us to prepare the final version of the manuscript. This research is financially supported by National Natural Science Foundation of China (grants 90202013 and 40371026) and the Chinese Academy of Sciences (grant Nos. KZCX3-SW-345, KZCX3-SW-339 and 2004102).

\section{REFERENCES}

Chen, J. 1988. Lichenometrical studies on glacier changes during the Holocene Epoch at the source region of Ürümqi River. Sci. China B, 18(1), 95-104. [In Chinese.]

Church, J.A. and 7 others. 2001. Changes in sea level. In Houghton, J.T. and 7 others, eds. Climate change 2001: the scientific basis. Contribution of Working Group I to the Third Assessment Report of the Intergovernmental Panel on Climate Change. Cambridge, etc., Cambridge University Press, 639-693.

Folland, C.K. and 9 others. 2001. Observed climate variability and change. In Houghton, J.T. and 7 others, eds. Climate change 2001: the scientific basis. Contribution of Working Group I to the Third Assessment Report of the Intergovernmental Panel on Climate Change. Cambridge, etc., Cambridge University Press, 99-181.

Kääb, A. and 6 others. 2002. Glacier monitoring from ASTER imagery: accuracy and applications. In Proceedings of EARSeLLISSIG Workshop 'Observing our Cryosphere from Space'. Bern, European Association of Remote-Sensing Laboratories. Special Interest Group Land Ice and Snow, 44-53.

Li, J. and 6 others. 1986. Glaciers in Tibet. Beijing, Science Press.

Lin, Z. and X. Wu. 1984. Climate in Lhasa at the early 20th century. J. Plateau Meteorol., 3(4), 14-20. [In Chinese.]

Liu, S., A. Lu, Y. Ding, T. Yao, L. Ding and G. Li. 2002. Glacier fluctuations and inferred climate changes in the A'nyêmaqên Mountains in the source area of the Yellow River. J. Glaciol. Geocryol., 24(6), 701-707.

Liu, S., W. Sun, Y. Shen and G. Li. 2003. Glacier changes since the Little Ice Age maximum in the western Qilian Shan, northwest China, and consequences of glacier runoff for water supply. J. Glaciol., 49(164), 117-124.

Mi, D., Z. Xie, X. Luo, Q. Feng, M. Ma and D. Jin. 2002. The Ganga drainage basin, Xi'an. In Glacier Inventory of China XI. Xi'an, $\mathrm{Xi}^{\prime}$ an Cartographic Press. [In Chinese.]

New, M., M. Hulme and P. Jones. 2000. Representing twentiethcentury space-time climate variability. Part II: development of 1901-96 monthly grids of terrestrial surface climate. J. Climate, 13(13), 2217-2238.

Pu, J., T. Yao, N. Wang, L. Ding and Q. Zhang. 2002. Puruogangri ice field and its variations since the Little lce Age of the northern Tibetan Plateau. J. Glaciol. Geocryol., 24(1), 87-92. [In Chinese with English abstract.]

Shi, Y. and C. Bai. 1988. Geomorphologic and climatic conditions of existence of Alpine glaciers in West China. In Shi, Y., M. Huang and B. Ren, eds. An introduction to the glaciers in China. Beijing, Science Press. [In Chinese.]

Shi, Y. and S. Liu. 2000. Estimation of the response of glaciers in China to the global warming in the 21 st century. Chinese Sci. Bull., 45(7), 668-672. [In Chinese.]

Shi, Y., S. Liu, D. Shangguan and B. Ye. 2006. Two peculiar phenomena of climatic and glacial variation in the QinghaiXizang (Tibetan) Plateau. Ann. Glaciol., 43 (see paper in this volume).

Su, Z. and Y. Shi. 2000. Response of monsoonal temperate glaciers in China to global warming since the Little Ice Age. J. Glaciol. Geocryol., 22(3), 223-229. [In Chinese with English summary.]

Wang, N. and L. Ding. 2002. Study on the glacier variation in Bujiagangri section of the east Tanggula range since the Little Ice Age. J. Glaciol. Geocryol., 24(3), 234-244.

Wang, N., L.G. Thompson and J. Cole-Dai. 2000. The nature of the solar activity during the Maunder Minimum revealed by the Guliya ice core record. Chinese Sci. Bull., 45(23), 2118-2124.

Wang, Z. 1991. The Little Ice Age of northwest China. J. Arid Land Res. Environ., 5(3), 64-74. [In Chinese with English abstract.]

Wang, Z. 1993. The glacier variation and influence since Little Ice Age and future trends in northwest region, China. Sci. Geogr. Sin., 13(2), 97-104. [In Chinese with English abstract.] 
Warrick, R.A., C. le Provost, M.F. Meier, J. Oerlemans and P.L. Woodworth. 1996. Changes in sea level. In Houghton, J.T., L.G.M. Filho, B.A. Callander, N. Harris, A. Kattenberg and K. Maskell, eds. Climate change 1995: the science of climate change. Cambridge, etc., Cambridge University Press, 359-405.

$\mathrm{Wu}$, X., L. Sun and Z. Cheng. 1988. Foundation of some tree chronologies in Tibet. Chinese Sci. Bull., 33(8), 616-619.

$\mathrm{Wu}$, X., L. Sun and X. Zhan. 1989. A preliminary study on reconstructing past climate in the middle Xizang Plateau by using tree-ring data. Acta Geogr. Sin., 44(3), 334-342.

Yao, T., K. Jiao, Z. Yang and W. Shi. 1995. Climate change since the
Little Ice Age recorded in the Guliya Ice Cap. Sci. China B, 25(10), 1108-1114. [In Chinese.]

Zeng, Q., Y. Deng and Y. Wang. 2000. Ice and snow disasters and their prevention. In Shi, Y., ed. Glaciers and environments past, present and future. Beijing, Science Press. [In Chinese.]

Zhang, S., J. Lu and S. Liu. 2001. Deriving glacier border information on Qinghai Tibet by TM high spectrum image. Geomatics Inf. Sci. Wuhan Univ., 26(5), 435-440. [In Chinese.] Zhang, Y., K. Fujita, Y. Ageta, M. Nakawo, T. Yao and J. Pu. 1998. The response of glacier ELA to climate fluctuations on HighAsia. Bull. Glacier Res., 16, 1-11. 